\title{
Bir Kentin Anlamına Erişme Üzerine: Dilsel Bir Varlık Olarak Antakya
}

\author{
$*$ \\ Benan Dönmez ${ }^{1}$ \\ ORCID: 0000-0001-8018-2796
}

Öz

Kent, içerisinde birçok varlığı barındıran bir bütün olarak, anlamı ve dilsel ifadesi sürekli olarak değişen bir yapıdadır. Bu çalışma da, kent ve dil ilişkisi üzerinden bir kenti anlama üzerinedir.

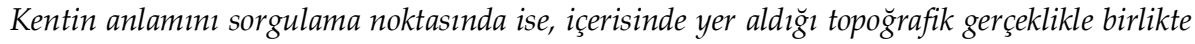
Antakya kenti çalışmanın öznesi olarak ele alınmıştır. Çünkü Antakya kenti ve var olduğu yeryüzü arasındaki ilişkinin çeşitli dilsel bileşenler üzerinden okunabilirliği, bu kent üzerinden inşa edilen anlamların deşifresini kolaylaştırmaktadır. Çalışma, dilsel bir yapıyı bizzat kuran kavramlar olarak anlatılar, ifadeler, temsiller, adlandırmalar üzerinden Antakya kentini okumayı amaçlamaktadır. Öyle ki, Antakya kentine dilsel bir varlık perspektifinden bakılarak, kentin anlamına varlığın anlamına erişir gibi yaklaşılır. Dolayısıyla, çalışmanın ilk bölümünde Antakya kenti varlığın doğrudan kendisi olarak kabul edilerek, bir varlık ve varoluş anlatısı aracılığıyla, kentin "varoluşsal mekânının keşfi üzerine" dilsel bir okuma gerçekleştirilmiştir. Antakya kentinin dilsel varlı̆̆ ve ifadesi, yer aldığı yeryüzüne ait beden üzerinden anlam kazanırken, varoluş mekân olan yeryüzünün bileşenlerinden dağ ve nehir temsillerinin anlamsal karşılıklarn da varlı̆̆ın kendisi ile birlikte dönüşmektedir. Bahsedilen anlamsal dönüşüm doğrudan dildeki ifadeye de yansıyarak adlandırmalardaki dönüşüm olarak ortaya çıkmaktadır. Çalışmanın ikinci bölümünde "dilsel dönüşümün deşifresi üzerine" bir okuma gerçekleştirilmiştir. Görülür ki, varlık dönüşen anlamını doğrudan dildeki yansıması üzerinden ifade etmektedir. Çünkü, anlamın bedenleşmesi dil üzerinedir.

Anahtar Kelimeler: Dil, anlam, varlık, varoluşsal mekân, Antakya

\footnotetext{
${ }^{1}$ Arş. Gör., Hatay Mustafa Kemal Üniversitesi, E-mail: benandonmez@hotmail.com idealkent (c) Kent Araştırmaları Dergisi (Journal of Urban Studies) 


\title{
On Reaching the Meaning of a City: Antakya as a Linguistic Being
}

\author{
Benan Dönmez² \\ ORCID: 0000-0001-8018-2796
}

\begin{abstract}
The city as a whole containing many beings, has a structure whose meaning and linguistic expression are constantly changing. This study is on comprehending a city through its relationship with language. While questioning the meaning of city, Antakya with its topographic reality is considered as the subject of study. Reading the relationship between Antakya and the earth through various linguistic components will support deciphering meanings constructed over this city. The study aims to read Antakya through narratives, expressions, representation, naming, which are the concepts constituting a linguistic structure. By considering Antakya as a linguistic being, the meaning of city is approached as if reaching the meaning of being. The first chapter is a linguistic reading, based "on discovering existential space" through an existence narrative, by accepting Antakya as the being itself. The linguistic expression of Antakya gain meaning through the body of the earth. As seen on the mountain and the river, the semantic equivalents of the earth transform with the city. This semantic transformation emerges as the transformation in naming. The second chapter is a reading, based "on deciphering linguistic transformation". Being expresses its transformed meaning through its reflection in language. Because, the embodiment of meaning is on language.
\end{abstract}

Keywords: Language, meaning, being, existential space, Antakya

2 Res. Asst., Hatay Mustafa Kemal University, E-mail: benandonmez@hotmail.com

idealkent (c) Kent Araştırmaları Dergisi (Journal of Urban Studies)

http://idealkentdergisi.com

Geliş Tarihi Received Date: 01.06.2020 Kabul Tarihi Accepted Date: 14.12.2020 


\section{Giriş}

Çağlar içerisinde kent, insan ile olan etkileşiminde anlamı ve dilsel ifadesi sürekli olarak değişen bir olgu olmuştur. En genel anlamıyla ise kent, içerisinde birçok varlığı barındıran bir bütündür. Kenti, 'içerisinde' varlıklara zemin sağlayan pasif bir pozisyonda görmenin ötesinde, diğer varlıklar -ve hatta kendi varoluşsal mekânı- ile 'birlikte' var olan, yaşayan bir varlık olarak anlamlandırmak da mümkündür. Tam da bu noktada, bir kenti anlamak için varlığın doğrudan kendisi olarak kenti sorgulamak, kente dilsel bir varlık perspektifinden bakmak, kentin varoluş hikayesini ortaya çıkarmak ve dolayısıyla anlam ile dil ilişkisindeki dönüşümleri keşfetmek üzerinden fenomenolojik bir yöntem tercih edilmektedir. Yer aldığı yeryüzüne ait topoğrafik gerçeklikle birlikte üzerine odaklanılacak kent ise, antik dönemde Doğunun Kraliçesi (Orientis Apicem Pulcrum) olarak tanımlanan Antakya kenti olacaktır.

Kentin dilsel bir varlık olarak kabul edildiği bir okuma için, ele alınan kentin 'anlam' sorgulamasında, kentin yer aldığı varoluşsal mekânı ile kurduğu derin ve doğrudan ilişki son derece önemlidir. Antakya kenti kendi varoluş anlatısını doğrudan yeryüzünün bileşenlerinden bir tarafta dağ (Silpius ya da Habib-i Neccar Dağı) ve diğer tarafta da nehir (Orontes ya da Asi Nehri) üzerine temellendirerek çok güçlü bir ilişkisellik kurmaktadır. Öyle ki, Christian Norberg-Schulz (1979, s.23-49) "Genius Loci: Towards a Phenomenology of Architecture" adlı kitabında, anlam kurucular olarak yeryüzüne dikkat çekmekte, benzer şekilde dağ ve su kavramlarına işaret etmektedir. 'Dağ' yeryüzüne (earth) ait olup göğe (heaven) yükselen bir imge olarak tam da "varlı̆ın (Being) yapısını tezahür ettiren" bir anlamlandırmada iken, "suyun varlı̆̆ 1 da yere kimlik veren" bir tanımlamadadır (Norberg-Schulz, s.25-27). Antakya kenti için hem yapısal (tektonik) bir gerçeklik, hem de çeşitli yönlerden mitsel bir oluş olan yeryüzü imgeleri, ortaya konmuş böyle bir kuramsal zeminin üzerinde bu çalışma ile birlikte yeniden inşa edilebilecektir. Yeryüzünün yapılı olanla ilişkisi meselesi, David Leatherbarrow $(2000 ; 2004)$ tarafından yazılan "Uncommon Ground: Architecture, Technology and Topography" ve "Topographical Stories: Studies in Landscape and Architecture" adlı çalışmaların da konusu olmuş ve yeryüzünün ötesinde artık 'topoğrafya' (topography) kavramına dönüşmüştür. Leatherbarrow'a göre (2004, s.13), "topoğrafya, sadece ifade edici ve gösterge niteliğinde değil, aynı zamanda ilişkiseldir; hayata dokusunu, zenginliğini ve kendiliğindenliğini veren zıt ortamların mozaik bir bütünleşmesidir". Bu noktada, örneğin, "Topoğrafyanm Anlamın Yeniden Düşünmek (ve 
İstanbul Deneyimi...)" adlı çalışma (Özbek Eren, 2019), açıkça bahsedilen yaklaşımlar üzerine temellenerek, İstanbul kentinin var olduğu topoğrafyası ile olan etkileşiminden edindiği anlam üzerine bir okuma gerçekleştirmektedir. Tüm bu çalışmaların öncesinde ise, Edmund Husserl (1940, s.307-325) tarafından 1934 yılında yazılan ve 'beden' (Körper) üzerinden bir yeryüzü söylemi kurgulayan "Grundlegende Untersuchungen zum phänomenologischen Ursprung der Räumlichkeit der Natur" adlıçalışma yer almaktadır. Varlık, varlığın anlamı ve yer aldığı dünya (Welt) -ve hatta yeryüzü (Erde)- üzerine fenomenolojik bir yaklaşım kuran Husserl (1940, s.308), dünya içerisinde sadece bir zemin (Boden) olarak var olan nesnel bir bedenin (Boden-Körper) ötesinde, diğer bedenleri de içererek aslında bir bütüne ilişkisel bir zemin (Erdboden) sağlayan bir bedene (Totalkörper) işaret etmektedir. Varlı̆̆ı yer aldığı çevre ile birlikte ele alan bir yaklaşımın izleri de, Richard Sennett'in (1994) "Flesh and Stone: The Body and the City in Western Civilization" adl kitabinda, kent ve beden arasında bir ilişkisellik kurma olarak ortaya çıkmaktadır. Sennett (1994, s.15), "Antik dönem Atinasindan modern dönem New York'a" bedenin anlamı ve kente olan yansıması üzerinde durmaktadır. Kent ve beden ilişkisi, Peter Ackroyd'un (2000) "London: The Biography" adlı kitabında da, Londra kentinin bizzat bir 'beden' olarak ele alınmasıyla görülebilmektedir. Ackroyd'un (2000) perspektifinden Londra kenti, hem fiziksel yapısı, hem de canlı varlığı ile 'yaşayan bir beden'dir. Antakya kenti de, dünya üzerindeki varoluşsal konumu, var olma biçimi, yeri ile birlikte sürekli olarak dönüşerek hem yeniden var olma hem de yeniden var etme durumu ile açıkça yaşayan bir bedendir.

Antakya kenti, doğu ve batının birleşme noktasında, çok çeşitli kültürel katmanları barındıran, dini bir merkez olması özelliğiyle dünyanın ilk kilisesinin ve Anadolu'nun ilk camisinin yer aldığı bir kenttir. Hiristiyan kelimesinin ilk kullanıldığı ve Hıristiyanlığın ilk Hac merkezi olan, ticaret ağlarının merkezinde ve ipek yolu üzerinde olması dolayısıyla dünyanın aydınlatılan ilk caddesinin bulunduğu, son derece önemli ve anlamlı kentler arasında yer almaktadır. Dilsel bir varoluş anlatısı olan bu çalışma için, bu kent çeşitli meselelerin 'ilk var olduğu yer' olması dolayısıyla da ayrıcalıklıdır. Çünkü kent bir varlık olmanın ötesinde varoluşsal mekânın doğrudan kendisi de olmakta, atfedilen roller hem kentin hem de yer aldığı yeryüzünün anlamını ve dilsel ifadesini dönüştürmektedir. Antakya kentinin dünya tarihi içerisinde kritik bir pozisyonda yer alması, bir varlık olarak kentin kendi varoluş mekânı ile kurduğu yapısal ve poetik ilişkiyi de desteklemektedir. Bu çalışma aracılığıyla kenti bir varlık olarak gören fenomenolojik bir yazım için, Antakya kenti bahsedilen sebeplerden dolayı uygun bir zemin sunmaktadır. 
Kent ve dil ilişkisi üzerinden, bir varlık olarak Antakya kenti ve varoluşsal mekânı olarak yeryüzünü anlama noktasındaki okumaya ise, anlatılar, ifadeler, temsiller, adlandırmalar gibi dilsel bir yapıyı bizzat kuran dilsel bileşenler aracılığıyla yaklaşmak hedeflenmektedir. Çünkü, varlık dönüş̧en anlamını doğrudan dildeki yansıması üzerinden ifade eder.

Kentin bir varlık olarak kabul edildiği noktada, varlığın dil üzerinden inşa edilmiş anlamının deşifresi önem kazanmaktadır. Fenomenolojik söylem, doğası gereği kendi içerisinde çok farklı yaklaşımlar ve adlandırmalar ile varlık konusuna yaklaşmaktadır. Martin Heidegger (1927/1996, s.21), Yunan felsefesinde "tanımlanamaz" ve zaten "herhangi bir tanım gerektirmez" olarak görüldüğünü belirttiği 'Being' kavramını varlik/oluş ile eşleştirmiş ve anlamını ortaya çıarma üzerine derin bir arayışa girmiştir. Heidegger'e göre (1927/1996, s.127); Being kavramının anlamına, "salt bir varlık sorunu" üzerinden gerçekleştirilecek bir tartışma ile erişilemez. Çünkü varlık (Being), diğer şeyleri (Things) ve varlıkları da içeren, nesnel bir gerçeklik içerisinde var olmaktadır. Varlığı (Being) yalın haliyle anlamlandırmanın ötesine geçen bu yaklaşım, beraberinde diğer dilsel kavramlar olan 'Dasein (being there)' ve 'being-in-the-world' kavramlarını üretir (Heidegger, 1927/1996). 'Dünya içinde varlık' (being-in-the-world) ile varlığ tanımlı bir yere yerleştiren bu adlandırma, varlığın "varoluşsal mekânsallı̆̆ı" (existential spatiality) ile olan kaçınılmaz karşılıklı ilişkisel gerçekliğini gündeme getirir (Heidegger, 1927/1996, s.83). Varlığın varoluşsal mekânı ile birlikte, kavramlar üzerinden dilin soyut mekânsallığı da böylelikle üretilir.

Heidegger felsefesinde 'oluş' üzerinden anlam kazanan varlık, Maurice Merleau-Ponty'nin (1945/1962, s.vii) fenomenolojik bakışında 'öz' (essence) üzerinden karşılığını bulmaktadır. Varlığın yaşayan ve derin tarafı üzerine odaklanılarak gerçekleştirilen ele alma biçimindeki bu değişim, beraberinde dili de dönüştürür. Being üzerine temellenen bir dil kullanılarak anlamı sorgulanan varlık, artık 'beden' (body) aracilığıyla tanımlanır. Merleau-Ponty'e göre (1964/1968, s.136); beden, hem duyumsanan (objective body) hem de duyumsayan (phenomenal body) tarafı ile aslında "iki boyutlu bir varlık" (the flesh) anlamındadır. Özne ve nesne rollerinin iç içe geçtiği hali ile, varlık varoluşunu yer aldığı dünyanın içinde (being-in-the-world) kalarak gerçekleştirmekle yetinmez, aksine dünya ile birlikte (being-with-the-world) karşllklı var olma savindadır. 


\title{
Varoluşsal Mekânın Keşfi Üzerine
}

\author{
Şiir, \\ insanı ilk olarak yeryüzüne getiren, \\ onu oraya ait kulan, \\ ve böylece mesken tutmasını sağlayan şeydir.
}

Martin Heidegger (1971/2001, s.216)

Varlığın dilsel anlamını açığa çıkararak izlerini takip etmek, insanı ve içerisinde yer aldığı yapısal çevreyi okuma noktasında özellikle yol gösterici olacaktır. Tam da bu noktada, içerisinde birçok varlığı barındıran bir bütün olarak kentin kendisini doğrudan bir oluş, varlık ya da beden olarak görmek, kentin anlamına erişmenin (ve hatta kent gerçekliğine ait yeni bir anlam üretmenin) temel meselesidir. Hem fenomenolojik yöntemin hem de tarihsel gerçekliğin söylemsel ve dilsel işaretleri ile etkileşim kurulacak kent olarak Antakya, bu varlık ve varoluş anlatısının asıl öznesidir. Bahsedilen dilsel anlatı ise, varoluş mitinin görece şiirsel (poetic) dili üzerine temellenmek, yere ait adlandırmaların izini sürmek, gezginlerin notları ve çizimleri ile seyahatnamelerdeki ifadelendirmeleri irdelemek ve dönüşümü açığa çıkarmak üzerinedir.

Fenomenolojik felsefeden referansla, bir varlık olarak kent, oluşunu fiziksel bir gerçeklik olan dünya üzerine yerleşerek (being-in-the-world) maddeleştirir. Antakya kentinin de üzerinde kurularak varlığını oluşturmaya başladığı mekânı, kentin özüne dönme ve anlamını kavrayabilme noktasında belirleyici bir veri olacaktır. Çünkü varlık, varoluş mekânı ile birlikte dönüşerek (being-with-the-world) anlamın kazanır. Varlığın tek başına olma halinin ötesinde, karşılıklı ilişkilerin bir sonucu olduğu gerçeği, Merleau-Ponty'nin beden kavramına atfettiği tanımlamanın da asıl meselesidir. Dolayısıyla kent ve üzerine konumlandığı dünya zemini (tüm çevresel bileşenleri ile birlikte), karşılıklı var olma hallerinden dolayı artık yaşayan birer beden olarak tanımlanabilir.

Antakya kentinin de dünya üzerine konumlanarak bizatihi varlığını gerçekleştirdiği zemin, artık hem bu kente ait varoluşsal yapıyı doğrudan şekillendirmekte, hem de doğmakta olan bu kentsel yapıyla birlikte dönüşerek açıkça özelleşmektedir. Dünya üzerindeki bu zemin, Heidegger (1950/2002, s.21) tarafından da "kendi içinde ve diğer şeylerde ortaya çıkma" ilişkiselliğine atıfta bulunularak "yeryüzü" (earth) olarak tariflenir. Dolayısıyla, "dünya (world) ve yeryüzü (earth) temelde farklıdır, ama asla birbirinden ayrı değildir. Dünya yeryüzünde kurulur ve yeryüzü dünyadan yükselir" (Heidegger, 
1950/2002, s.26). Böylelikle, Antakya kenti de üzerinden -ve hatta doğrudan içinden- doğmakta olduğu "yeryüzünün yeryüzü olmasına izin verir" (Heidegger, 1950/2002, s.24).

Glanville Downey (1963, s.11-12), antik dönemde Antakya kentinin kurulduğu yer üzerine tanımlama yaparken, bu yeri olağanüstü olarak tarifler. Bu olağanüstülüğü temsil eden unsurlar ise, "bir tarafında şehrin kurulduğu kuzeydoğudan güneybatıya akan Orontes Nehri (the Orontes)", "nehir boyunca uzanarak yükselen muhteşem Silpius Dağı (Mount Silpius)", "düz bir zemin olan bereketli Amik Ovası (Amuk Plain)" gibi coğrafyaya ait olan topoğrafya özellikleridir. Christian Norberg-Schulz (1971/1974, s.28), bu gibi coğrafyaya ait mekânların içerdiği yerlerin ve yolların soyut bir karaktere sahip olduğundan bahsetmektedir. Çünkü coğrafyanın kendisinin oluşturduğu bu mekânlar zaten açıkça bilinir olanı temsil etmezler, ancak varoluşsal mekânın (existential space) potansiyel unsurlarıdır (Norberg-Schulz, 1971/1974, s.28). Antakya kentinin dilsel varlığı ve ifadesi de, içerisinde yer aldığ 1 özel coğrafyanın topoğrafik bileşenlerinin bütünü olan yeryüzüne ait beden üzerinden anlam kazanır. Ancak, bedenin "iki boyutlu bir oluş" (Merleau-Ponty, 1964/1968, s.136) olduğu gerçeği, madde ile anlamın, fizik ile metafiziğin bir aradalığını savunur. Dolayısıyla, Antakya kentinin varlığı, sadece yapısal olan (tectonics) üzerine değil, aynı zamanda şiirsel olan (poetics) üzerine de düşünmeyi gerektirir.

Kentin anlatımında topoğrafyanın bedenine yapılan atıflar, özellikle gezgin notları ve seyahatnamelerdeki dilde de açıkça görünür durumdadır. Wilbrands von Oldenburg (1859, s.50) 1211 yılında gerçekleştirdiği Antakya ziyaretinde, çok büyük bir nehir ile kentin çok büyük ve dik üç dağından bahseder. Bu dağlardan özellikle ortadaki bulutlara kadar o kadar yükselir ki, gezegenlerin rotalarını dahi bozacağı düşünülür. Oldenburg, bu dağın uçurumlarında dinlenilmek amaçlı yaratılan bir varlık olduğuna inandığından söz eder. 1549 yılında Antakya'ya gelen Jean Chesneau da (1887, s.145) kente dair notlarında "büyük ve yüksek dağlar"a değinir. Benzer şekilde, Evliya Çelebi de Seyahatname'sinde (1848/2006, s.72), 1648 yılında gittiği Antakya'yı, doğu tarafındaki kale duvarları neredeyse "gökyüzüne karışmış", "yüksek ve büyük dağlar" üzerine kurulmuş bir kent olarak tarifler. Kentin dil üzerinden ifadesinde ortak bir durum olarak, içerisinde yer aldığı fiziksel gerçekliğe ait topoğrafik imgelerin etkisi öncelikli olarak görülür. Bir yanda yükselerek kente dikey bir boyut katan dağ imgesi ile diğer yanda bu etkiyi olabildiğince güçlendirir nitelikte yatayda uzanan nehir imgesi, kenti asıl tanımlayan unsurlardır. Öyle ki, kentin dilsel ve söylemsel varoluşu, çevresel 
unsurların oluşturduğu topoğrafik bir mekânsallık ve bu topoğrafyanın kente olan neredeyse metafizik etkisi üzerinden anlamını bulmaktadır. Norberg-Schulz (1971/1974, s.7), varlığın çevresi ile hem madde aracılı̆̆ıyla fiziksel hem de anlam aracıllğıyla ruhsal ilişkiler kurarak elde ettiği bu mekânsallığı "varoluşsal mekân" (existential space) olarak tanımlamaktadır. Bahsedilen, varlığın sadece fiziksel olarak dünya üzerindeki herhangi bir yere basitçe konumlanmasıyla sonlanan değil, varlığa içerisinde yer aldığı çevre ile güçlü bir bağ kurarak anlamlı bir "tutunma noktası" (existential foothold) oluşturan bir ilişkidir (Norberg-Schulz, 1979, s.5). Antakya kentinin de yeri üzerinden inşa ettiği anlam, açıkça bir varlık olarak kente ait "yerin ruhunu somutlaştırma" (to concretize genius loci) meselesinin neticesidir (Norberg-Schulz, 1971/1974, s.36).

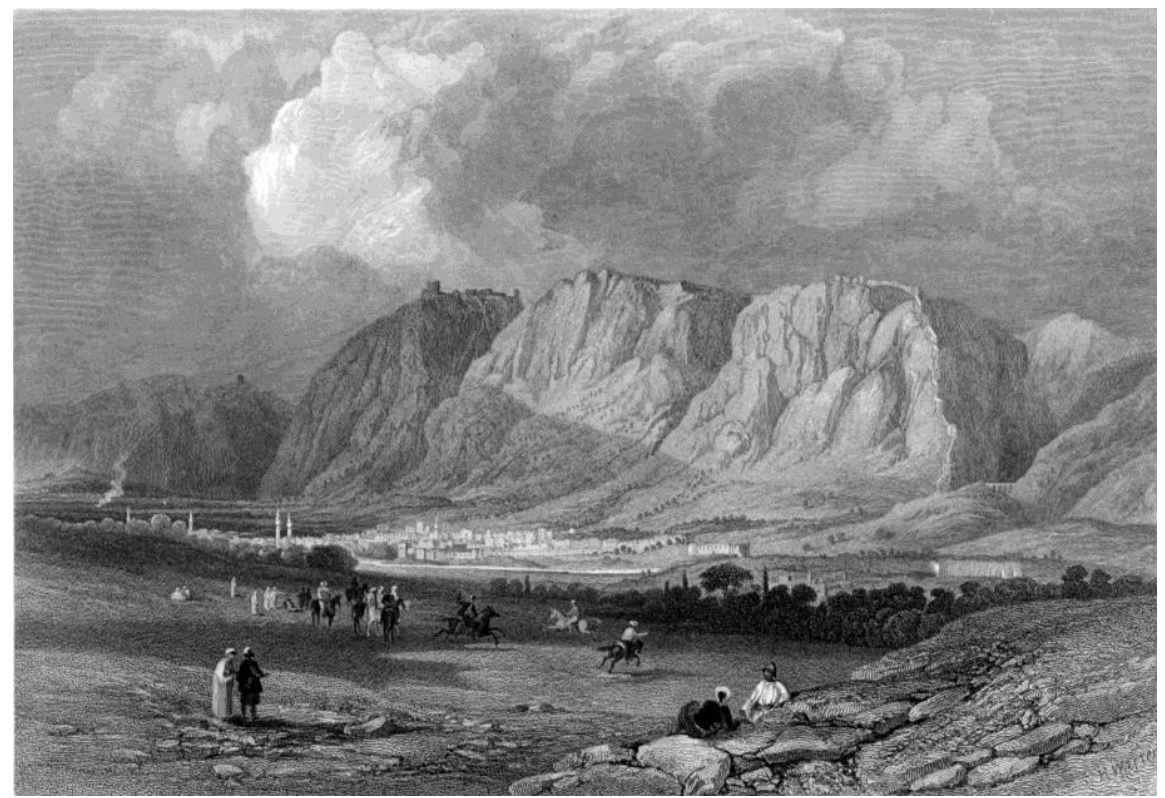

Şekil 1. Dağ ve nehir arasına yerleşen kent; William Miller tarafından yapılan bir gravür (Fairbairn, 1866, s.98-99) 


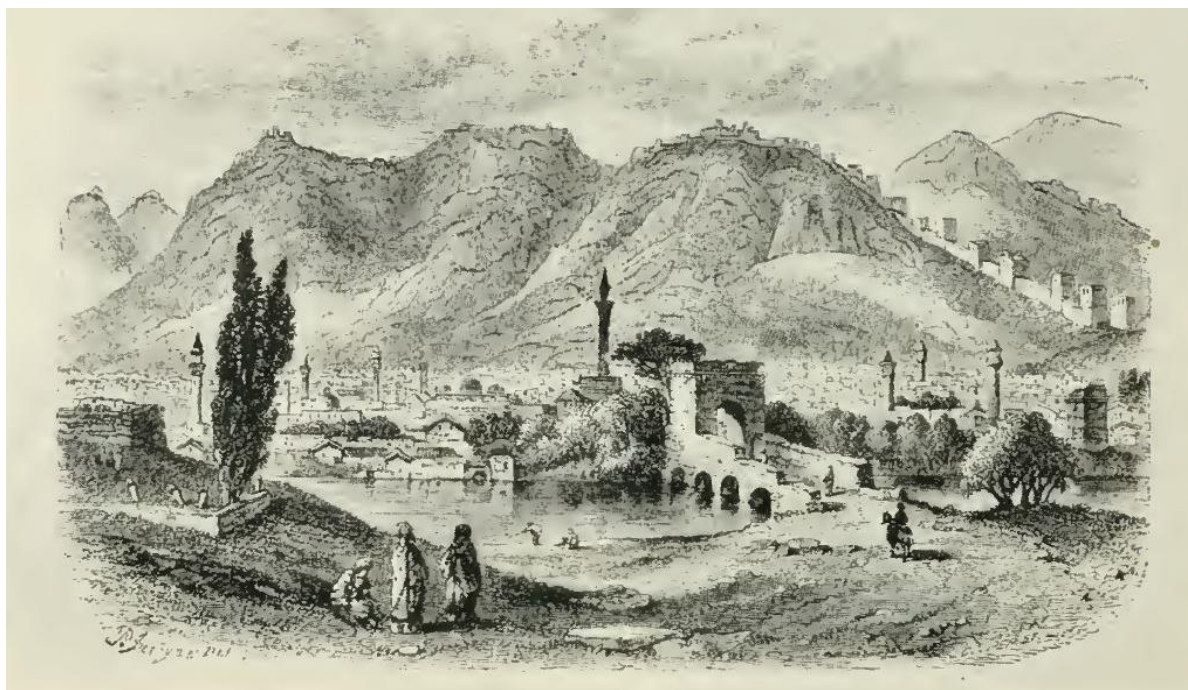

Şekil 2. Dağ ve nehir arasına yerleşen kent (Bouchier, 1921, s.Frontispiece)

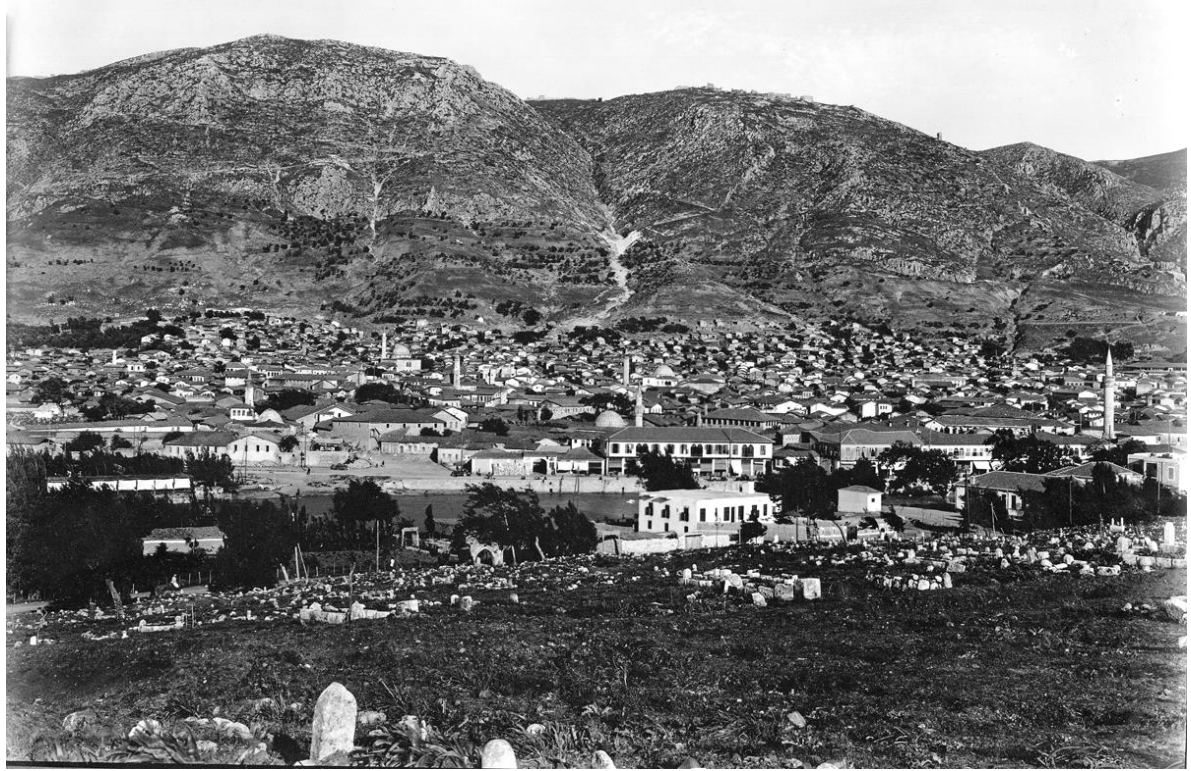

Şekil 3. Dağ ve nehir arasına yerleşen kent; kentin ilk arkeolojik kazısını gerçekleştiren Princeton Üniversitesi arşivinden 1933 yılına ait bir fotoğraf (Archaeological Archives, 1933)

Antakya kentinin varlığının somutlaşması üzerinde yeryüzünün ve topoğrafyaya ait fiziksel bedenin etkisi, kentin neredeyse bir varoluş anlatısı 
olan Antakya Tyche heykelinde de ayrıca görülür. Öyle ki, başına kentin surlarını temsil eden bir taç takmış olan bir kadın bedeni, açıkça Antakya kentine karşılık gelir. Kentin bir varlık olarak doğrudan kendisini temsil eden bu kadın bedeni, benzer şekilde Silpius Dağı'nı ifade etmekte olan bir kayaya oturur ve Orontes Nehri'ni temsil eden yüzen bir genç erkek bedenine basar. Aslında ifade edilen, açıkça yeryüzü zeminine ait dağ ve nehir imgeleri arasına yerleştiği vurgulanan, Antakya kentinin beden üzerinden somutlaşmış görüntüsüdür. Kenti temsil etmekte olan bu kadın bedeni, ayrıca elinde tuttuğu buğday başağı ile de bolluk ve bereket ifadesi üzerinden doğrudan yerleştiği yeryüzüne işaret etmektedir. Böyle bir anlatı aracılı̆̆ıyla, varlığın ve hatta bedenin kendisi olarak Antakya kenti, dünyadaki fiziksel bir gerçekliğe yerleşerek varoluşsal mekânını görünür kılar, varoluşunu başlatır ve varlığını varoluşsal mekanı ile birlikte anlamlandırır. Varlığın, içerisinde yer aldığı çevre ile kurduğu anlamlı ilişki, Heidegger (1971/2001, s.209-227) tarafından yeri "şiirsel olarak mesken tutma" (dwelling poetically) olarak tariflenir. Öyle ki, "yeryüzünün üstünde" olmak, aslında "gökyüzünün altında" olmaktır (Heidegger, 1971/2001, s.147). Dolayısıyla, varlık "yeryüzünün üzerinde ve içinde, dünyadaki meskenini bulur" (Heidegger, 1950/2002, s.24). Antakya kentinin üzerine yerleştiği topoğrafik gerçeklik de beraberinde bir derinliği üretmekte ve kentin anlamına metafizik bir boyut katmaktadır. Böyle bir anlamlandırma ile kent ve dünyasını kurduğu yeryüzü, gerçekliğin miti, maddenin ruhu, fiziğin metafiziği beraberinde gündeme getirdiği bir yerdir.

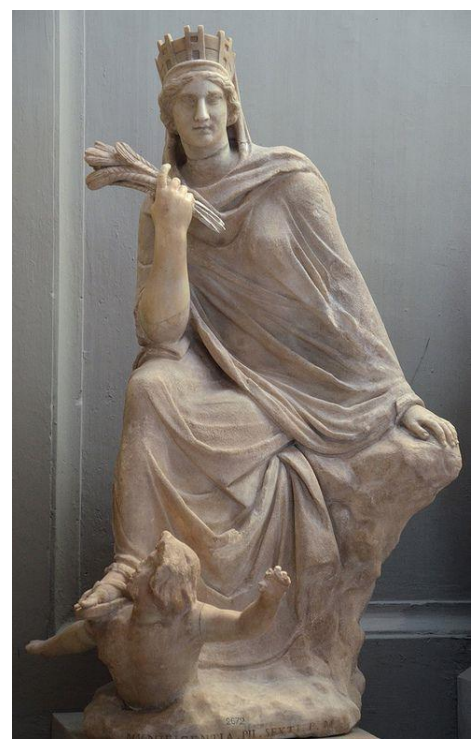

Şekil 4. Antakya Tyche Heykeli (Raddato, 2016) 

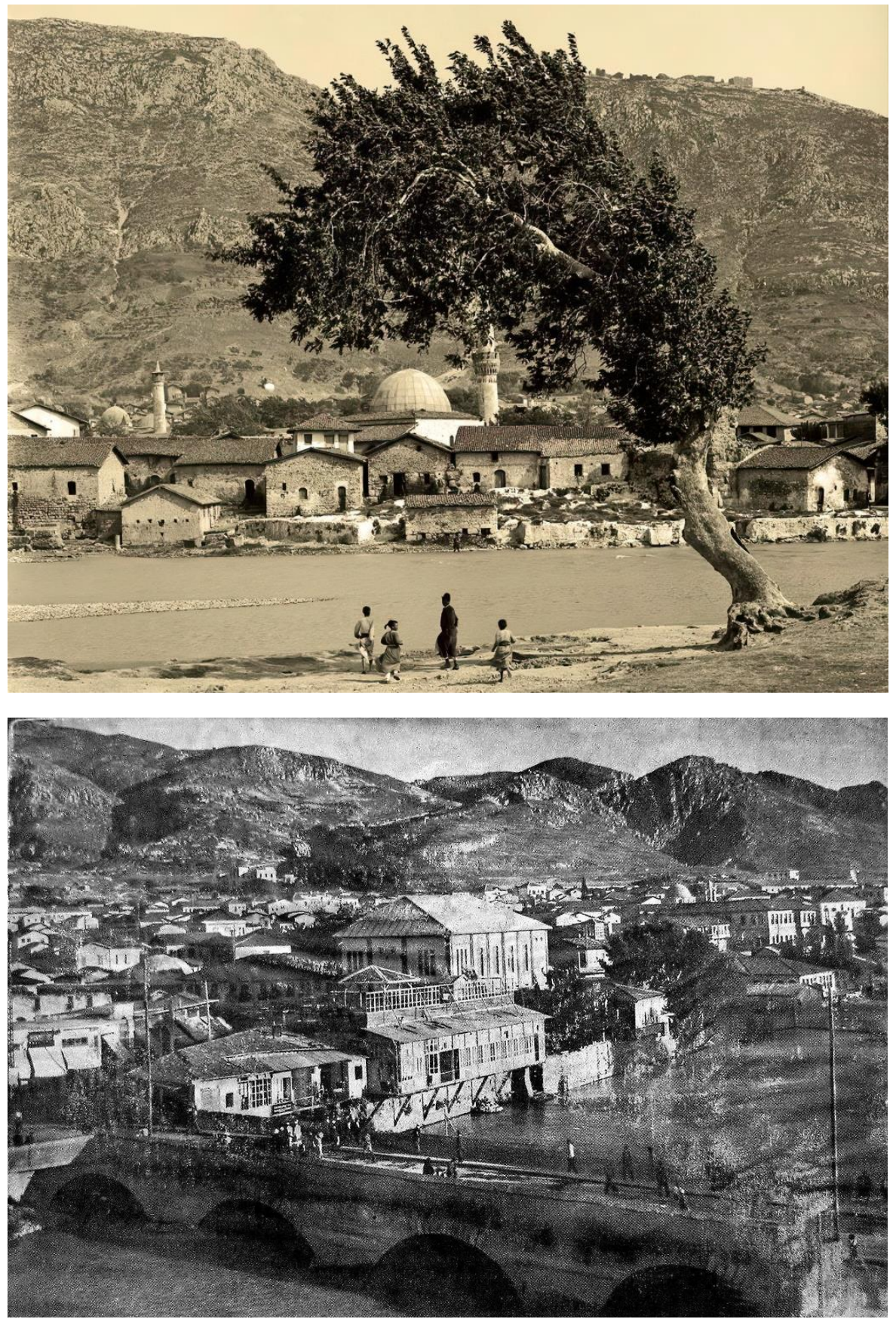

Şekil 5-6. Kent, dağ ve nehir ilişkisi; Eski Türkiye Fotoğrafları Arşivi'nden 1898 ve 1944 yıllarına ait fotoğraflar (Eski Türkiye Fotoğrafları Arşivi, 1898/1944) 


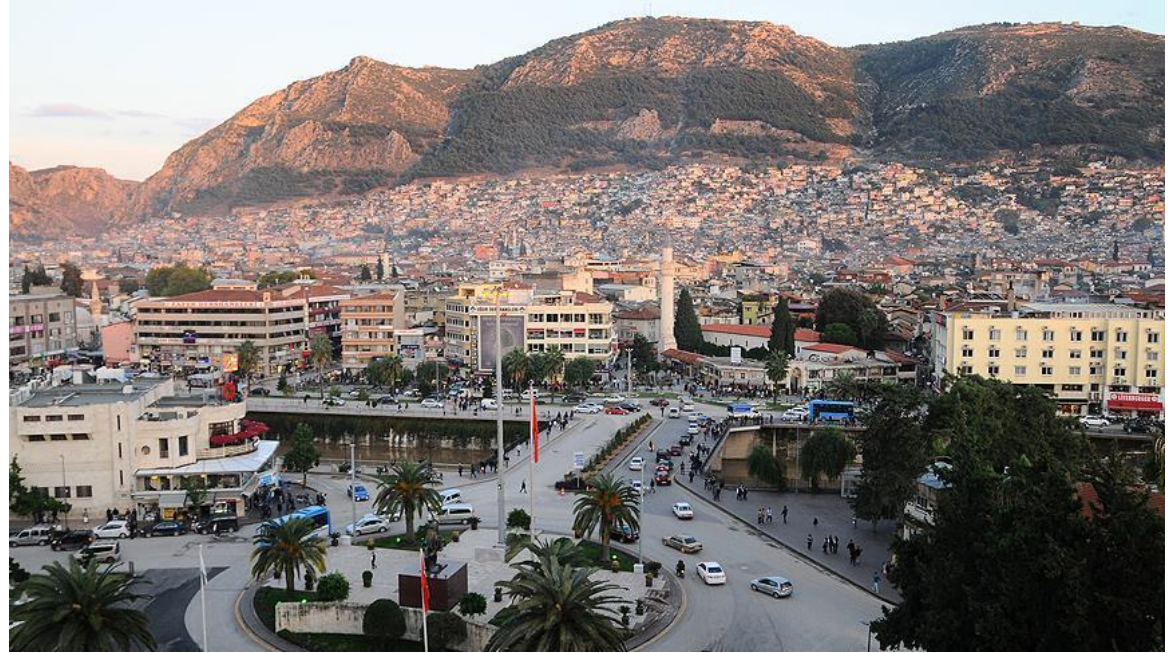

Şekil 7. Kentin dağla ilişkisi gösteren 2017 yılına ait bir fotoğraf (Anadolu Ajansı, 2017)

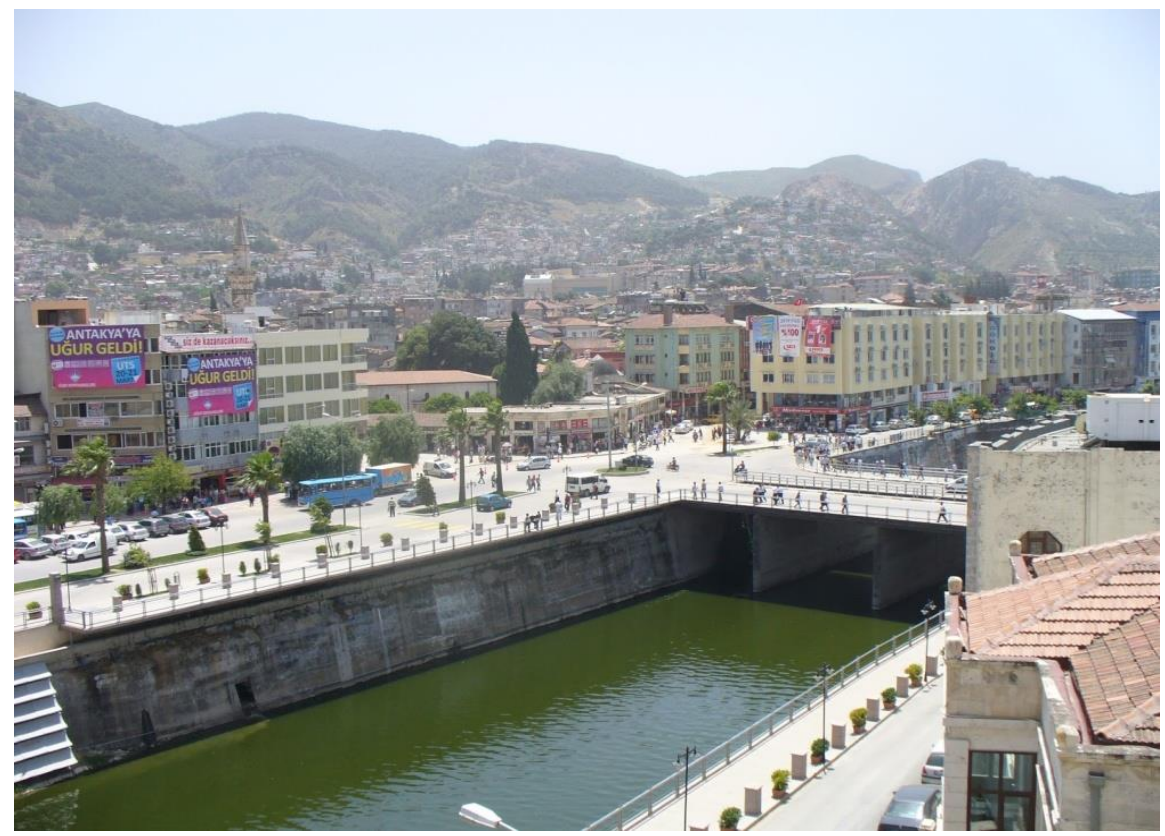

Şekil 8. Kentin nehirle ilişkisini gösteren 2018 yılına ait bir fotoğraf (Al-Kurdi, 2018)

Bir varlık olarak Antakya kentinin varoluş anlatısı, diğer her oluş, varlık ya da beden gibi doğumunu gerçekleştirdiği dünya içinde (being-in-the-world) sadece kendini var etmeye ilişkin değildir. Kentin bedeninin topoğrafyanın bedeni aracılığıyla ortaya çıkması, aslında varlı̆̆ın kendi ile birlikte (being-with- 
the-world) varoluş mekânını da dönüştürmesi demektir. Bu karşılıklı ve birlikte var olma hali, Merleau-Ponty (1964/1968, s.130-155) veSteven Holl (1996, s.11) tarafından "iç içe geçme" (intertwining) kavramı üzerinden ifade edilir. Heidegger (1950/2002, s.25) ise bu ilişkiselliği, varlıkların kendi sınılarının "ana hatlarının bulanıklaşmasına" izin vermeyecek şekilde, "karşılıklı uyum içerisinde birbiri içerisine akma" olarak tarifler. Bahsedilen, açıkça dağ ve nehir arasında var olan Antakya kentinin de, artık yer aldığı topoğrafik zeminin varoluşuna nüfuz edeceğidir. Varlıkların sınırlarını ve kendiliklerini yok etmeden, yeni bir ilişkisellik kurma üzerinden yeryüzünün anlamını sürekli olarak dönüştüreceği gerçeğidir. Öyle ki, dağ ve nehir farklı uzamsal boyutlardaki haliyle de olsa yeryüzünün sonsuz sürekliliğinin birer parçaları iken, kent bir varlık olarak tam da ikisinin arasında belirmeye başlar. Böylelikle artık sürekliliğinden ve sınırlandırılmamışlı̆ı̆ndan kaynaklı tek bir zeminden söz etmek mümkün değildir. Doğmaya başlayan kentin bedeni dünya düzlemine bir taraftan kendi içerisinde sinırlar getirirken, diğer taraftan bu sınırlama aslında her birini ayrı ayrı görünür kılar, tanımlar ve özneleştirir. Bu durum, kent ile birlikte yeryüzünün de yeniden var edilmesidir. Karşılıklı ilişkisellik içerisinde yeniden var olma hali, Antakya kentinin tarihsel süreci içerisindeki gelişimi ile birlikte sürekli olarak devam eder. Öyle ki, kent fiziksel büyümesini devam ettirdikçe dağa doğru yayllır ve yeryüzünün neredeyse bir parçası olarak dağ ile kurduğu ölçeği dönüştürür. Bu aslında varlıkların sınırlarının bir tür iç içe geçme (intertwining) ve birlikte var olma (with-the-world) iddiasıdır. Diğer yandan ise, nehirle doğrudan temas halindeki kent geriye çekilerek sınırları daha da belirgin kılar ve hatta başka yeni sınırlar üretir. Dolayısıyla varlık ve varoluşsal mekânı, yaşayan birer beden olarak birbirlerini dönüştürerek yeniden var ederler. Kurulan ilişkilerdeki dönüşüm de hem bir varlık olarak Antakya kentinin, hem de yer aldığg yeryüzünün anlamsal ve dolayısıyla dilsel dönüşüme sebep olur. Bu noktada, varlığın (Antakya) varoluş mekânı (dağ ve nehir) ile olan ilişkisinin dönüşümü, aslında tam da dilsel ve dolayısıyla anlamsal dönüşümlerinin izlerinde gizlidir.

\section{Dilsel Dönüşümün Deşifresi Üzerine}

Kelimenin olmadı̆̆ yerde hiçbir şey yoktur. Bir şeyin varlığl kelimede ikamet eder. Dil, varlığın evidir. 
Bir varlık olarak kentin anlamını açı̆̆a çıkarma girişimi, fenomenolojik bir bakış gereği, varlığın özüne erişebilmek adına "geriye dönmeyi" (to go back to the things themselves) (Husserl, 1900/1901, s.168) gerektirir. Bu noktada, tüm fiziksel gerçekliği ile zaten mevcutta var olan dünya zemininin sayısız potansiyel varoluş mekânı üzerinde, varlığın ilk belirdiği durumunu tümüyle keşfetmek esas meseledir. Varlığın varoluşsal mekânı, madde ile anlam, fizik ile metafizik, cisim ile ruh arasında gerçekleşen karşılıklı etkileşimin bir sonucudur. Dolayısıyla, bir geriye dönme müdahalesi içerisinde, Antakya kentinin de "iki boyutlu bir oluş" (the flesh) (Merleau-Ponty, 1964/1968, s.136) üzerinden açıklanması beklenen varlığı, sadece yapısal olan (tectonics) üzerine değil, aynı zamanda şiirsel olan (poetics) üzerine de düşünmeyi gerektirir.

Antakya kentinin (kentin bedeninin), dünyada üzerine yerleşerek varlık kazandığı varoluşsal mekânı da (existential space), hem rasyonel bir düşüncenin hem de mitsel bir anlatının sonucudur. Kentin kurucusu olan Seleucus I Nicator, krallığının batıdaki merkezi olarak önce Seleucia Pieria'yı (Samandağ) kurmuş, ardından bu yeni başkentin Seleucus Krallığ için sahip olması gereken bazı niteliklerden yoksun olduğu gerçeği ile daha iç kısımlarda yeni bir kent kurmaya ihtiyaç duymuştur. Malalas'ın tanrısal bir mit üzerine temellenen anlatısına göre; Antakya için bir yer işareti arayan Seleucus I Nicator, daha önce Seleucia Pieria kentinin kurulmasındaki inanışa benzer bir yöntem takip eder ve Antigonia'ya (mağlup ettiği Antigonus'un yönetim merkezi olan kent) giderek,

Antigonus'un yaptırdığı mabedde Zeus'a bir kurban daha keser ve ondan kendisine bir yol göstermesini diler. Yeni bir kent mi kurmalıdır, yoksa Antigonia'yı yeniden imar ederek ismini değiştirmekle mi yetinmelidir? Kartal kurban etini kaparak uçar ve Antigonia'dan başka bir yere konar. Zeus'un, yeni kurulmasını istediği kentin yerinin burası olduğuna inanılır ve İÖ 300 senesi 22 mayısında Iopolis'in karşısında, Silpius eteğinde kentin temelleri atılır ve yeni kente Seleucus'un babası (ya da oğlu) Antiochus'un adı verilir: Antiocheia (Demir, 1996, s.24-25).

İsmi verilen kent, edindiği dilsel kimliği üzerinden artık dünya üzerinde anlamlı bir varlık olarak tanımlanabilecektir. Michel Foucault (1966/2001, s.164) tarafından "bir temsili ayağa kaldırma" olarak tanımlanan adlandırma ile, Antakya kentinin varoluş mitinin dilsel anlatısı, bulunduğu yer ile birlikte bedenleşerek maddesel gerçekliğine kavuşur. Oluşun bedenleşmesinin varlık ve varlığın varoluşsal mekânı üzerine olduğu noktada, anlamın bedenleşmesi dil üzerinedir. Çünkü, "dil, ilk olarak varlıkları adlandırarak, onları önce dile getirir ve görünür kılar" (Heidegger, 1971/2001, s.71). 


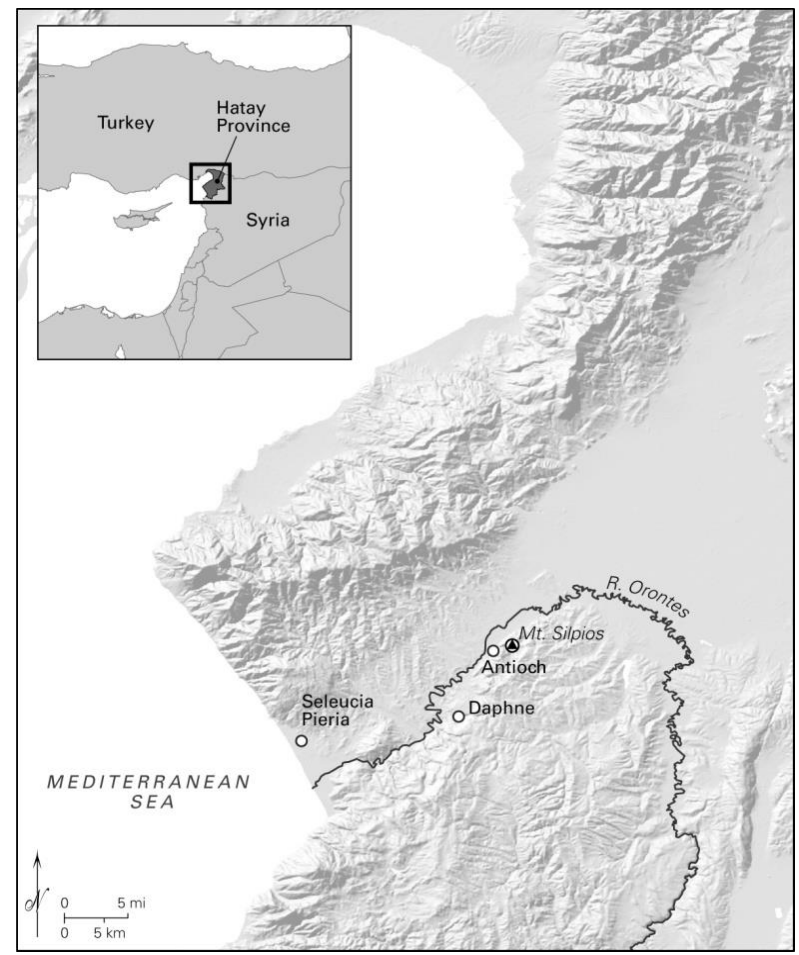

Şekil 9. Antakya kentinin dünya üzerindeki yeri ve çevresini gösteren Scott Walker tarafından düzenlenmiş harita (Walker, t.y.)

Seleucus I. Nicator ile ismi verilen kentin varlığı, aslında şïrsel bir anlatının yanı sıra, son derece akılcı ve planlı bir kararın neticesinde de mekânını bulur. Stratejik bir hamle olarak ve askeri amaçlarla yeni kenti daha iç kısımlarda kurma düşüncesi ile, Antakya kenti krallığın kurulan diğer kentlerinin (Seleucia Pieria (Samandağ), Apamea (Epemiye), Laodicea-on-the-Sea (Lazkiye)) aynı genel tasarım özellikleri izlenerek, Seleukos kolonileşme planının bir parçası olarak kurulur (Downey, 1963, s.28-29). Buna göre;

Kentlerin çoğunluğunda standart bir plan uygulandı. Bu planın başlıca özellikleri, kenti ikiye ayıran ve diğer sokakların yönlenmesini belirleyen bir ana eksenel yol, konut adalarının planlamasında basit matematiksel oranların kullanımı ve bağımsız olarak tahkim edilmiş kente hâkim bir kale idi.... Sokak sistemi dikdörtgen bir plana sahipti fakat pusulanın ana yönlerine göre yönlendirilmemiştir. En az beş uzun cadde ve bunları kesen çok sayıda sokaktan oluşmaktaydı. Bundan ortaya çıkan konut adaları eşit bir biçimde 112 metre $x$ 58 metre boyutlarındaydı. Roma döneminde muhteşem sütunlu bir ana yola dönüşen 27 metre genişliğindeki uzun merkezi cadde yaklaşık 3 kilometre bo- 
yunca kenti katetmekteydi. Kent surları kentin çevresinde düzensiz bir güzergah izleyerek doğuda bağımsız bir biçimde tahkim edilmiş olan kale ile buluşmaktaydılar (Owens, 1991/1996, s.80-81).

Kentin nesnel tanımlaması bu denli açık ortaya konmakta olan yapısı ile görülür ki, metafizik üzerine kurulu şiirsel anlam, artık fizik üzerine kurulu bir maddesellik ile birleşir. Böylece Antakya kenti üzerine yerleştiği topoğrafik gerçeklik (-in-the-world) ile birlikte (-with-the-world) dönüşür. Kent yeryüzü (earth) üzerinden anlamlı bir beden (body) olarak varlık kazanırken, varoluş mekânı olan yeryüzünün bileşenlerinden dağ ve nehir de kentle birlikte her defasında ilişkisel, anlamsal ve dilsel olarak yeniden var olur.

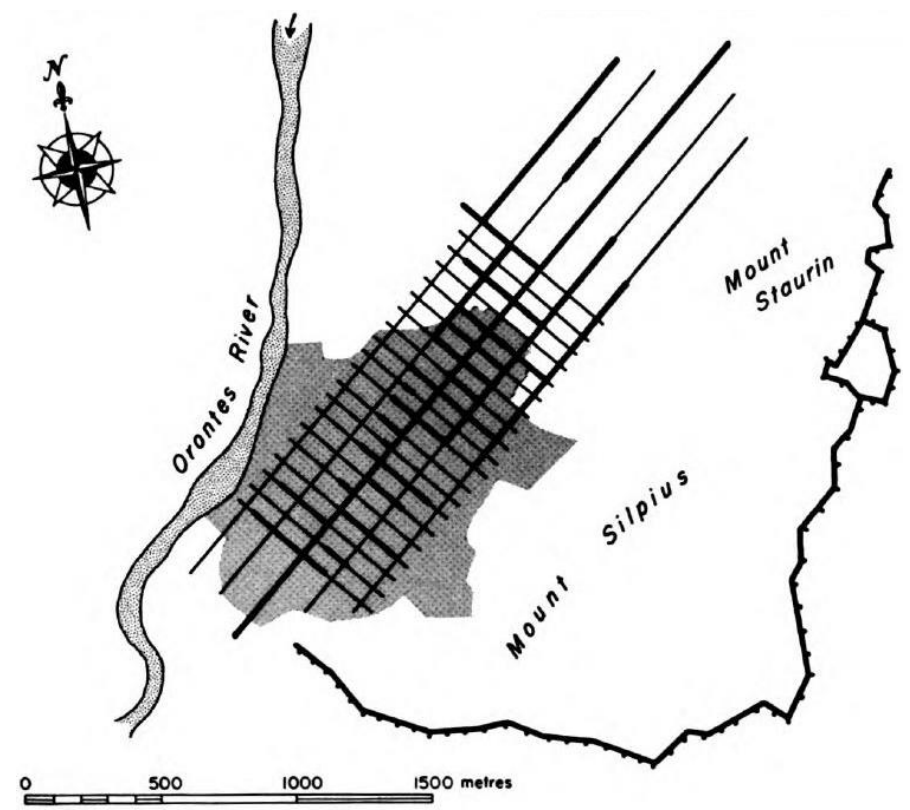

Şekil 10. Antakya kentinin Jean Sauvaget tarafından 1934 yılında çizilen yerleşim ve planlama haritası (Downey, 1961, s.763)

Antioch ile dilsel varlığını kazanan kent, zaman içerisinde temsil ettiği anlamı ve adlandırılmasında (toponimi) bir dönüşüm ve çeşitlenmeyi de beraberinde getirir. En yaygin olarak, "Antioch the Great" (Büyük Antakya), "on the Orontes" (Asi üzerindeki), "of Syria" (Suriye'nin) ve görece daha az da olsa "Antioch by Daphne" (Defne (Harbiye) yakmındaki Antakya) gibi tanımlamalar ile nitelendirilir (Bouchier, 1921, s.1). Hiristiyanlık dininin dünya üzerinde ilk ortaya çıktığı yer olması (ve hatta Hıristiyan (Christian) isminin ilk defa Antakya kentinde verilmesi) ve daha sonra İslamiyet döneminde de yine dini önemini 
devam ettirmesi, kentin ayrıca din üzerinden bir anlam ve adlandırma da edinmesini sağlar. Birçok dilde "Tanrının Şehri" anlamlarına gelen "Medinetullah", "Medine-i İlahiyye", "Cite de Dieu", "Teupoli", "Theoupolis", "Divine City" gibi isimler böylelikle Antakya kentine atfedilmiştir (Tozlu, 2009, s.2729). Antakya, aynı zamanda doğunun şehridir ve bu "yön" dolayısıyla Batılllar tarafından "Melike-i Şarkiyye (Doğu'nun Kraliçesi)" anlamına gelen "Ren Doriyan (Reine D'Orient)" ve "the Queen of the East", "Doğunun Güzel Kraliçesi" anlamina gelen "Orientis Apicem Pulcrum (Fair Crown of the Orient)" ve "Durretü'ş-Şarku'l-Cemile (Şark'ın Güzel İncisi)" gibi bazı isim ve sifatlar kullanılarak tanımlanmıştır (Tozlu, 2009, s.27-29). Böylece, kentin adlandırılmasında (toponimi), anlamsal dönüşüme ek olarak, dilsel dönüşümün izleri de belirgin şekilde gözlenir. Evliya Çelebi, Seyahatnamesi'nde (1848/2006, s.68-69) çok eski bir belde olduğu için her dilde birer özel isim ile isimlendirildiğinden bahseder. Öyle ki, "bazıları Entakiyye derler, niceleri Antakıyya, niceleri Ayntakıyye ve bazıları Antekye derler ama meşhur galatı Antakıyya ve Entakiyye'dir. Kupti dilinde Cebsiyan derler, Acemce'de An-takiyye derler.... An Takyanus'dan bozulma Antakıyya derler" (Çelebi, 1848/2006, s.68-69). Dolayısıyla, Antakya kentinin adlandırılmasındaki değişim üzerine böyle bir iz sürmenin neticesinde görülür ki, kent dönüşen anlamını doğrudan dildeki yansıması üzerinden ifade eder. Çünkü, "dil muhtevayı sorunsuzca aktaran saydam ve bağımsız bir ortam değil, bağlamsal ilişkiler içinde anlam üreten bir bildirimdir....Olguları oluşturan düşünceyi temsil ederken, düşünceyi hem biçim hem de içerik açısından hizaya sokan belirgin bir düzenleyici hatta inşacı rolü üstlenir" (Basa, 2016, s.96-101).

Kentin içerisinde yer aldığı topoğrafik gerçekliğin de zaman ve bağlam içerisinde dönüşen anlamının izleri, doğrudan bu gerçekliği temsil eden dil üzerinde görülür. Antakya kentine doğrudan ismini de veren (Antioch-on-theOrontes) ve antik dönemde the Orontes ('doğudan' anlamına gelen Orentes kelimesinden türer) olarak adlandırılan nehir, Makedonya nehir tanrısı adına "Axius", Orta Çağ Arapları tarafından "ters dönmüş (the overturned)" anlamına gelen "Al Urunt" ya da "Al Maklub", modern ismiyle "Asi" anlamina gelen "Nahr-el-Asi (the rebel river)", "hızl" anlamina gelen "Atzoio (the rapid)", Haçlilar tarafından Pharphar ve Chrysorhoas adlandırmaları ile tanımlanmıştır (Bouchier, 1921, s.3). Evliya Çelebi ise Seyahatnamesi'nde (1848/2006, s.75-77) Asi Nehri'nin varoluş hikayesinin mitsel bir oluş üzerine temellenen anlatısından bahseder. Anlatıya göre (1848/2006, s.75-77); Hazret-i Peygamber zamanında Hama şehri gayet susuz olup, İzail adında bir Yahudi Nil'i bu şehre getirip akıtmak üzere Mısır'a varır. Mansure şehri dibinde Nil'den dört şişe su alarak 
bir efsun okur ve Nil Nehri'nin bir parçası Yahudi'nin ardı sıra yeri yarıp gelir. Hazret-i Peygamber, Hazret-i Aliye Yahudi'yi durdurması için emr edince, Ali Yahudi'ye Gülbin Dağı eteğinde yetişir ve Yahudi'yi orada öldürür. Şişenin biri kırılarak yere dökülür ve büyük bir nehir batı tarafa doğru akar. Hazret-i Ali "Ey Asi Nehri, bütün nehirler Hakk huzuruna yönelip kıbleye doğru akar. Sen niçin batıya akarsın? Dön geri, asi oldun" deyince, nehir dile gelip "Ey Ali! Tanrı'nın emri ile bu mahalle gelmişken, Humus, Hama ve nice şehri sulayıp Antakya şehrinde Habib-i Neccar'ı ziyaret edip oradan yine kıbleye akayım" der ve böylece nehre adı verilir: Asi Nehri. Bahsedilen anlatı gibi bir mit; nehri, içerisinde yer aldığı topoğrafik gerçekliğe ve beraberinde de kente bağlayacak olan dil üzerinden bir anlam üretme halidir. Maddeyi açıkça yere bağlayan böyle bir ilişkiyi, Steven Holl $(1989$, s.9) yerle kurulması gereken "deneyimsel, metafiziksel ve şiirsel bir bağlantı" olarak adlandırdığ 1 "bağlanma/tutunma" (anchoring) kavramı ile tanımlar. Çünkü yer, fiziksel ve metafiziksel bir temeldir (Holl, 1989, s.9).

Kent ve nehir üzerinden ortaya çıkan böyle bir anlatıda olduğu gibi, önemli bir diğer topoğrafik gerçeklik olan dağ imgesi için de, imgenin dilsel varlığında gerçekleşen bir dönüşümden bahsedilebilir. Nehrin yataylı̆̆ının aksine, yükselerek kente bir derinlik katan "Silpius Dağı (Mount Silpius)", Hazret-i İsa'nın kente gönderdiği iki havarisine iman eden ve tek tanrı inancı dolayısıyla burada şehit edilen Habib-i Neccar'ın (Sevgili Marangoz) ismini alarak "Habib-i Neccar Dă̆g" olarak adlandırılmaktadır. Bu anlatının Kur'an'da Yasin Suresi'nde geçmesi dolayısıyla, Habib-i Neccar Müslümanlar için de ayrıca öneme sahiptir (Tekin, 1998, s.25-30). Üç tepeden oluşan dağın bir tepesi olan "Staurin (Haç) Dă̆ı (Mount Staurin)" ise, "Hıristiyan" adının ilk kez kullanıldığı ve dinin buradan yayıldığı mağarayı barındırması dolayısıyla yine din üzerinden ayrı bir anlama sahiptir. Kentin topoğrafyasına atfedilen anlamlar aracıllğıyla kentin dilsel ifadesini kazanması ve beraberinde topoğrafyaya ait adlandırmaların değişen anlamlara göre dönüşmesi, bir varlık olarak kentin dünya içerisindeki varoluşsal mekânını görünür kılar. Bir kentin anlamına erişme noktasında, kentin varoluşsal mekânsallığındaki fiziksel ve anlamsal her türlü değişim, açıkça kentin dilsel bir varlık olduğunun ispatidır.

\section{Tartışma ve Sonuç}

Kent, içerisinde birçok varlığı barındıran bir bütün olarak, anlamı ve dilsel ifadesi sürekli olarak değişen bir yapıdadır. Ancak kent de aynı şekilde fizik- 
sel bir dünya gerçekliği üzerine tıpkı diğer varlıklar gibi yerleşir. Bu çalışmada, kentin anlamını sorgulama noktasında üzerine yerleştiği topoğrafik gerçeklikle birlikte Antakya kenti varlığın doğrudan kendisi olarak kabul edilmektedir. Böylece, Antakya kenti bir varlık ve varoluş anlatısının asıl öznesi olur. Dolayısıyla, Antakya kentine dilsel bir varlık perspektifinden bakllarak, kentin anlamına varlığın anlamına erişir gibi yaklaşılmıştır. Görülür ki, kentin dilsel varlığı ve ifadesi, doğrudan içerisinde yer aldığı yeryüzüne ait beden üzerinden anlam kazanmaktadır. Kentin anlatımında sürekli olarak topoğrafyanın bedenine yapılan atıflar ise, doğrudan bu fiziksel gerçekliğin de anlamının irdelenmesini gerektirmiştir. Çünkü, varlığın kendisi olarak kent, varoluş mekânı ile birlikte dönüşerek anlamını kazanır. Antakya kentinin varoluş anlatısı doğrudan yeryüzünün bileşenlerinden bir tarafta dağ (Silpius ya da Habib-i Neccar) ve diğer tarafta da nehir (Orontes ya da Asi Nehri) üzerinde varlık kazanırken, yeryüzü de kentle birlikte sürekli olarak yeniden var olmaktadır. Antakya kenti ve tüm çevresel bileşenleri ile üzerine konumlandığı dünya zemini, karşılıklı var olma hallerinden dolayı yaşayan birer beden olarak görülür.

Kentin var olduğu yeryüzü ile birlikte sürekli değişen anlamına erişmek için gerçekleştirilen tüm girişimler, dışarıdan bir bakışın ötesinde, kentin doğrudan özünü görmeye eğilimli bir arayışa ihtiyaç duymaktadır. Dünya üzerindeki diğer varlıklar gibi Antakya kentinin kendisini de bir varlık olarak düşünmek, kentin bir oluş hikayesinin mümkünlüğünü de dile getirmek demektir. Varlığa görece şiirsel bir derinlik de katabilecek varoluşsal anlatı, aslında varlığın dil üzerinden ilerlemesi muhtemel anlam arayışının en belirgin yol göstericisi olmuştur. Böylelikle, dilsel bir anlatı üzerinden, kentin varlığ hem şïrsel hem de yapısal olanın ifadesi aracılığıyla anlam kazanır.

Antakya kenti, çok özel bir coğrafyada ve dilsel ifadesi evrilmeye çok hazır bir bağlamsal çeşitlilik içerisinde yer almaktadır. Nehir ve dağ gibi fiziksel gerçeklikler, kentin dil üzerinden ifadesinde etkisi çok derece baskın imgelere dönüşmektedir. Dolayısıyla, kentin dilsel varlığı, sadece yapısal olan (tectonics) üzerinden değil, aynı zamanda şiirsel olan (poetics) üzerinden de açığa çıkmaya ihtiyaç duymaktadır. Antakya kentinin anlatılar, ifadeler, temsiller, adlandırmalar çerçevesinde kurgulanan anlatımında topoğrafyanın bedenine doğrudan yapılan atıflar, kentin üzerinde yer aldığı yeryüzü ile basit bir konumlanma ilişkisi içerisinde olmadığını, aksine bir tür mesken tutma eylemi içerisinde olduğunu kanıtlamaktadır. Öyle ki, bir varlık olarak kent, varoluşsal mekânı ile karşılıklı bir oluş halindedir. Bu sürekli oluş hali, hem An- 
takya kentinin topoğrafya ile kurduğu ilişkiyi dönüştürerek aslında yeryüzünü sürekli olarak yeniden var etmekte, hem de kentin ve bulunduğu topoğrafik gerçekliğin dil üzerinden temsilinde bir dönüşümü beraberinde getirmektedir.

Dağ ve nehir farklı uzamsal boyutlardaki halleriyle de olsa yeryüzünün sonsuz sürekliliğinin birer parçaları iken, Antakya kenti bir varlık olarak tam da ikisinin arasında belirmeye başlamıştır. Doğmaya başlayan kentin bedeni dünya düzlemine sınılar getirmeye başlamakta ve bu sınırlamalar ile aslında her biri ayrı ayrı görünür kılınarak yeniden var edilmektedir. Kentin tarihsel süreci boyunca devam eden değişimler, varlıkların kendileri ve birbirleriyle olan ilişkiselliğini doğrudan etkilemektedir. Antakya kenti, fiziksel büyümesini devam ettirdikçe Habib-i Neccar Dağı'na doğru yayılmış ve dolayısıyla artık yeryüzünün neredeyse bir parçası olma noktasına evrilerek, dağ ile kurduğu ölçeğini dönüştürmüştür. Diğer yandan, Antakya kenti Asi Nehri ile yer yer neredeyse iç içe geçerek doğrudan temas ve etkileşim halinde iken, kent geriye doğru çekilmiş ve görece ilişkisini zayıflatmıştır. Dolayısıyla, varlık ve varoluşsal mekânı, yaşayan birer beden olarak birbirlerini dönüştürerek yeniden var etmektedirler.

Kentin yeryüzünü dönüştürmesinin izlerinin ise en çok görüldüğü nokta, özellikle yeryüzü parçalarından dağ ve nehrin anlamsal ve dolayısıyla da dilsel ifadeleri ile adlandırmalarındaki dönüşümlerinde olmaktadır. Denilebilir ki, oluşun bedenleşmesinin yansıdığı yerin varlık ve varoluşsal mekânı olduğu noktada, dönüşen anlamın bedenleşmesinin izinin sürülebildiği yer dildir. Çünkü; "dil, insanın (ve tabi varlığın) içinde yaşayarak var olduğu, onu koruyarak varlığın hakikatine ait olduğu varlığın evidir (Heidegger, 1977/1993, s.237)". İçerisinde yer aldığı zemin ile birlikte devamlı olarak yeniden adlandırılan Antakya kenti, edindikleri dilsel kimlik üzerinden dünya üzerinde anlamlı bir varlık olarak tanımlanabilmektedir. Öyle ki, "algılanan şeyi dünyanın bir parçası yapan isimdir ve dolayısıyla onu anlamlı bir algı haline getirir" (Norberg-Schulz, 1984/1985, s.111). Bir kentin anlamına erişme noktasında ise, birlikte gerçekleşen her türlü fiziksel ve anlamsal değişim, içerisinde yer aldığı gerçeklikle birlikte kentin dilsel bir varlık olduğunun kanıtidir. 


\title{
Extended Abstract
}

\section{On Reaching the Meaning of a City: Antakya as a Linguistic Being}

\author{
$*$ \\ Benan Dönmez \\ ORCID: 0000-0001-8018-2796
}

Through the ages, the city has been a phenomenon whose meaning is constantly changing in its interaction with people. In general terms, the city is a whole that contains many beings. Beyond seeing the city in a passive position that only provides ground for the beings ' $i n$ ' itself, it is also possible to make sense of it as a living being that coexists 'with' other beings. At this point, a phenomenological method is preferred that questions a city as the being itself, looks at the city from a linguistic perspective and reveals the city's existence story. The city to be focused on is decided to be Antakya city which was identified as the Queen of the Orient (Orientis Apicem Pulcrum) in ancient times.

At the point where the city is accepted as a being, deciphering the linguistic meaning of the being becomes important. Following the traces of the linguistic meaning by revealing it especially will be guiding in reading the being and the structural environment in which it is located. Antakya, as the city to interact with the discursive and linguistic signs of both the phenomenological method and historical reality, is the main subject of this being and existence narrative. This linguistic narration is realized through grounding on the poetic language of the existence myth, tracing the naming of the place, examining the notes and drawings of travelers and the expressions in travelogues, and revealing the transformation.

The references to the body of the topography in the narrations of the city are clearly visible especially in the language of traveler notes and travel books. The mountain image (Mount Silpius or Habib-i Neccar Mountain) which adds a vertical dimension to the city by rising and the river image (the Orontes or Asi River) lying horizontally which enhances this dimension effect are the main elements that define the city. The linguistic and discursive existence of 
the city gain the meaning through a topographic spatiality created by environmental elements and the metaphysical effect of this topography on the city. As a common situation in the expression of the city through language, the effect of the topographical images belonging to the physical reality in which the city is located has priority. The topographical reality on which Antakya city is located produces a depth with it and adds a metaphysical dimension to the meaning of the city. With such a meaning, the city is a place where the reality brings the myth and the physics brings the metaphysics to the agenda. Existential space of being is the result of this reciprocal interaction. Hence, the existence of Antakya city, which is expected to be explained through its two dimensional being (the flesh), requires considering on not only the tectonics, but also the poetics.

The existential space where Antakya city (and even its body) settled on inthe-world is the result of both a rational thought and a mythical narrative. The definition of the city based on its objective side shows that the poetic meaning based on metaphysics is combined with a materiality based on physics. Thus, Antakya city becomes a meaningful being that is transformed by the topographical reality on which the city settled.

Like any other existence, being or body, the existential narrative of Antakya city is not only about the existence of itself in the world (being-in-the-world). The emergence of the body of the city through the body of topography actually means the transformation of the existential space with itself (being-withthe-world). That is to say, Antakya city, which clearly exists between the mountain and the river, will penetrate into the existence of the topographic ground on which it is located. It is the fact that it will continually transform the meaning of the earth through establishing a new relationality without destroying the boundaries of beings and their selves. So much so that while the mountain and the river are the parts of the infinite continuity of the earth, albeit in different spatial dimensions, the city begins to appear as an entity exactly between the two. Thus, it is not possible to talk about just a single ground. On the one hand, the body of the city, which has begun to born, brings borders to the world plane, on the other hand, this limitation actually makes each one visible and makes them subject by defining each one. This situation is the re-creation of the earth as well as the city. The state of re-existence in a reciprocal relationality continues with the development of Antakya city in its historical process. That is to say, while the city continues its physical growth, it spreads towards the mountain and transforms the scale it establishes with the mountain by being a part of the earth. This is actually the claim 
that the boundaries of beings intertwine and beings exist together. On the other hand, the city, which is in a direct contact with the river, makes the borders clearer and even creates other new borders by retreating. Therefore, being and its existential space, traces of which are actually hidden in linguistic and semantic transformations, re-exist as living bodies by transforming each other.

The city, which has gained its linguistic existence by naming, brings also a transformation and variation in its meaning and naming over time. Such a trace on the change in the naming of Antakya city shows that the city expresses its transforming meaning through its reflection on language. Similarly, the traces of the meaning of the topographic reality in which the city is transformed by time and context are seen directly on the language that represents this reality. The city's gaining its linguistic expression through the meanings referred to the topography of the city and the transformation of the naming of topography according to the changing meanings makes the existential space of the city in-the-world visible. At the point of reaching the meaning of a city, any physical and semantic change in the existential spatiality of the city is clearly the proof that the city is a linguistic being.

\section{Kaynakça/References}

Ackroyd, P. (2000). London: The biography. London: Chatto \& Windus.

Al-Kurdi, Z. (2018, 4 Mart). The Cradle of Christianity - Antioch (Antakya). 28 Mayıs 2020 tarihinde http://www.beyondbethanytours.com/2018/03/the-cradle-of-christianity-antioch.html adresinden erişilmiştir.

Anadolu Ajansı. (2017, 1 Şubat). Expo 2021 Hatay'da yapılacak. 28 Mayıs 2020 tarihinde https://www.aa.com.tr/tr/turkiye/expo-2021-hatayda-yapilacak/739486 adresinden erişilmiştir.

Archaeological Archives. (1933). Committee for the excavation of Antioch-on-the-Orontes 1932-1939. Erişim adresi (28 Mayıs 2020): http://vrc.princeton.edu/archives/items

Basa, İ. (2016). Söylemsel zapturapt: Kamusal mekân eli (dili) ile kentsel kültürü ehlileștirmek. Arredamento Mimarlik Dergisi, 301, 96-101.

Bouchier, E. S. (1921). A short history of Antioch: 300 B.C. - A.D. 1268. Oxford: Basil Blackwell.

Chesneau, J. (1887). Le voyage de monsieur d'aramon - Ambassadeur pour le roy en levant. Paris: Ernest Leroux.

Çelebi, E. (2006). Günümüz Türkçesiyle Evliya Çelebi seyahatnamesi: Konya - Kayseri - Antakya - Şam - Urfa - Maraş - Sivas - Gazze - Sofya - Edirne (3. Cilt, 1. Kitap), Haz. S. A. Kahraman ve Y. Dağlı. İstanbul: Yapı Kredi Yayınları. (Orijinal çalışma 1848 yılında yayımlanmıştır). 
Demir, A. (1996). Çă̆lar içinde Antakya. İstanbul: Akbank Kültür ve Sanat Yayınları.

Downey, G. (1961). A history of Antioch in Syria: From Seleucus to the Arab conquest. Princeton, New Jersey: Princeton University Press.

Downey, G. (1963). Ancient Antioch. Princeton, New Jersey: Princeton University Press.

Eski Türkiye Fotoğrafları Arşivi. (1898/1944). Eski Türkiye fotoğrafları arşivi. Erişim adresi (28 May1s 2020): http://www.eskiturkiye.net/arama/antakya

Fairbairn, P. (1866). The imperial bible-dictionary - Historical, biographical, geographical and doctrinal, (vol. I). London: Blackie and Son, Paternoster Row.

Foucault, M. (2001). Kelimeler ve şeyler - Insan bilimlerinin bir arkeolojisi (M. A. Kılıçbay, Çev.). Ankara, İstanbul: İmge Kitabevi Yayınları (Orijinal çalışma 1966 yılında yayımlanmiştır).

Heidegger, M. (1982). On the way to language (P. D. Hertz, Çev). New York: Harper \& Row Publishers (Orijinal çalışma 1959 yılında yayımlanmıştır).

Heidegger, M. (1993). Letter on humanism (F. A. Capuzzi ve J. G. Gray, Çev.). D. F. Krell (Ed.), Basic writings: From being and time (1927) to the task of thinking (1964) (s.217265) içinde. New York: HarperCollins Publishers. (Orijinal çalışma 1977 yılında yayımlanmıştır).

Heidegger, M. (1996). Being and time (J. Macquarrie ve E. Robinson, Çev.). Oxford: Blackwell Publishers (Orijinal çalışma 1927 yılında yayımlanmıştır).

Heidegger, M. (2001). Poetry, language, thought (A. Hofstadter, Çev). New York: Harper Perennial Modern Classics (Orijinal çalışma 1971 yılında yayımlanmıştır).

Heidegger, M. (2002). The Origin of the work of art. (J. Young ve K. Haynes, Ed. ve Çev.), Off the beaten track içinde (s.1-56). Cambridge: Cambridge University Press. (Orijinal çalışma 1950 yılında yayımlanmıştır).

Holl, S. (1989). Anchoring. New York: Princeton Architectural Press.

Holl, S. (1996). Intertwining. New York: Princeton Architectural Press.

Husserl, E. (1940). Grundlegende untersuchungen zum phänomenologischen ursprung der räumlichkeit der natur. (M. Farber, Ed.), Philosophical essays in memory of Edmund Husserl içinde (s.307-325). Cambridge: Harvard University Press. (Orijinal çalışma 1934 yılında yazılmış, 1940 yılında yayımlanmıştır).

Husserl, E. (2001). Logical investigations - Volume II (J. N. Findlay, Çev.). London: Routledge \& Kegan Paul. (Orijinal çalışma 1900/1901 yılında yayımlanmıştır).

Leatherbarrow, D. (2000). Uncommon ground: Architecture, technology and topography. Cambridge, Mass.: The MIT Press.

Leatherbarrow, D. (2004). Topographical stories: Studies in landscape and architecture. Philadelphia: University of Pennsylvania Press.

Merleau-Ponty, M. (1962). Phenomenology of perception (C. Smith, Çev.). London: Routledge \& Kegan Paul. (Orijinal çalışma 1945 yılında yayımlanmıştır).

Merleau-Ponty, M. (1968). The visible and the invisible (A. Lingis, Çev.). Evanston: Northwestern University Press. (Orijinal çalışma 1964 yılında yayımlanmıştır). 
Norberg-Schulz, C. (1974). Existence, space and architecture. New York: Praeger Publishers (Orijinal çalışma 1971 yılında yayımlanmıştır).

Norberg-Schulz, C. (1979). Genius loci: Towards a phenomenology of architecture. New York: Rizoli.

Norberg-Schulz, C. (1985). The concept of dwelling - On the way to figurative architecture. New York: Rizzoli International Publication (Orijinal çalışma 1984 yılında yayımlanmiştır).

Oldenburg, W. V. (1859). Reise nach Palaestina und Kleinasien (J. C. M. Laurent, Çev.). Hamburg: Theodor Gottlieb Meissner.

Owens, E. J. (1996). Yunan ve Roma dünyasında kent (C. Bilsel, Çev.). İstanbul: Homer Kitabevi. (Orijinal eserin yayın tarihi 1991).

Özbek Eren, İ. (2019). Topoğrafyanın anlamını yeniden düşünmek (ve İstanbul deneyimi...). Megaron YTÜ Mimarlkk Fakültesi E-Dergisi, 14(2), s.196-204.

Raddato, C. (2016). The tyche of Antioch. 28 Mayis 2020 tarihinde https://www.flickr.com/photos/carolemage/30770583730/ adresinden erişilmiştir.

Sennett, R. (1994). Flesh and stone: The body and the city in western civilization. New York; London: W. W. Norton \& Company.

Tekin, H. (1998). Habib Neccar of Antakya (N. Çinçin, Çev.). Antakya: Zirem Basımevi.

Tozlu, S. (2009). Antakya (Hatay) tarihi bibliyografyası. Elazığ: Fırat Üniversitesi Basımevi.

Walker, S. (t.y.). K. M. Coleman (2018), Late Roman mosaics at the institute for advanced study içinde. https://www.ias.edu/ideas/coleman-mosaics adresinden erişilmiştir. 